\title{
Temperature and Seed Moisture Govern Germination and Storage of Gerbera Seed
}

\author{
William J. Carpenter and Eric R. Ostmark \\ Department of Environmental Horticulture, Institute of Food and Agricultural \\ Sciences, University of Florida, Gainesville, FL 32611
}

John A. Cornell

Department of Statistics, Institute of Food and Agricultural Sciences, University of Florida, Gainesville, FL 32611

\section{Additional index words. Gerbera jamesonii, seed desiccation, seed cold tolerance}

\begin{abstract}
Temperature, relative humidity (RH), desiccation, and hydration affect gerbera (Gerbera jamesonii H Bolus ex Hook.f.) seed storage and germination. Germination percentages $(G)$ were maximal and about equal at constant 15,20 , or $25 \mathrm{C}$ in darkness or light but lower at alternating temperatures having the same mean temperature. The number of days to $50 \%$ final germination $\left(T_{50}\right)$ and between $10 \%$ and $90 \%$ germination $\left(T_{90}-T_{10}\right)$ required the fewest days at constant 25 or $30 \mathrm{C}$; longer germination periods resulted with alternating temperatures. Reducing seed moisture from $7.1 \%$ to $3.5 \% \mathrm{had}$ no effect on $G, T_{50}$, or $T_{90}-T_{10}$ values, but at seed moisture levels $<3.5 \%$, $G$ was lower and $T_{50}$ and $T_{90}-T_{10}$ longer. Germination percentages were similar after seed storage from 5 to $-5 \mathrm{C}$, but $\mathrm{G}$ was lower after storage at $-10 \mathrm{C}$ or lower. Low-temperature seed storage had no effect on $T_{50}$ or $T_{90}-T_{10}$ values. Seeds had highest $G$ and lowest $T_{50}$ and $T_{90}-T_{10}$ values when germinated at $52 \%$ seed moisture, with large declines and delays in germination at lower and higher moisture levels. Seed storage for 12 months without reduction in germination was possible at $5 \mathrm{C}$ and $11 \%$ or $32 \% \mathrm{RH}$. Seeds stored at $52 \% \mathrm{RH}$ lost $\mathrm{G}$ at all temperatures, and no seed germinated after storage at $75 \% \mathrm{RH}$ and 15 or $25 \mathrm{C}$. Seed stored at 5 or $15 \mathrm{C}$ and $11 \%$ to $32 \% \mathrm{RH}$ had the fewest days to $T_{50}$ and $T_{90}-T_{10}$.
\end{abstract}

Plant breeders have developed gerbera strains for cut flowers, bedding and landscape plantings, and flowering pot plants. Gerbera are propagated primarily from seed, although meristem-tip culture procedures are commonly used by commercial micropropagation laboratories. Post (1949) recommended gerbera propagation by seed or division but provided no information for germinating seeds. Ball (1991) reported 21 to $24 \mathrm{C}$ as the optimum temperature range for germination and further suggested seeds be covered with finely shredded sphagnum peat. Our literature search found no other recommendations for seed storage or germination. Year-round propagation, production, and sale of plants has increased growers' need for more information on gerbera seed storage and germination. Our research objectives were to determine light, seed moisture, and temperature requirements during germination and to evaluate the effects of temperature, relative humidity ( $\mathrm{RH})$, and seed desiccation during seed storage.

Received for publication 16 May 1994. Accepted for publication 12 Oct. 1994. Florida Agriculture Expt. Station Journal series no. R-03799. We acknowledge the seed source and partial funding of this research by a grant from the Earl J. Small Growers, Pinellas Park, Fla. The cost of publishing this paper was defrayed in part by the payment of page charges. Under postal regulations, this paper therefore must be hereby marked advertisement solely to indicate this fact.

\section{Materials and Methods}

Seed handling and germination procedures. 'Painted Center Dark Eye' seeds, used in all our studies, were harvested by Earl J. Small Growers, Pinellas Park, Fla., on 14 Sept. 1992. After receipt on 30 Sept., seeds were dusted with $3 \alpha, 4,7,7 \alpha$-tetrahydro-2-[(trichloromethyl) thio]-1- $H$-isoindole-1,3 (2H) dione (cap$\tan )$. All treatments contained four 100 -seed replications, each of which was germinated in individual $9-\mathrm{cm}$ petri dishes on blue blotter paper 100 (Anchor Paper Co., Charlotte, N.C.) and moistened with $5 \mathrm{ml}$ of distilled water (DW) unless otherwise designated. Germination studies were conducted in incubators (Stults Scientific Engineering Corp., Springfield, Ill.). In each study, germination counts were made daily of seeds with radicle protrusion through the testa. Total germination percentages $(\mathrm{G})$, the number of days to $50 \%$ final germination $\left(\mathrm{T}_{50}\right)$ and between $10 \%$ and $90 \%$ germination $\left(\mathrm{T}_{90}-\mathrm{T}_{10}\right)$ were calculated as described by Furutani et al. (1985).

Light and temperature studies. Imbibed seeds were kept in darkness or in continuous incandescent light at $15 \mu \mathrm{mol} \cdot \mathrm{m}^{-2} \cdot \mathrm{s}^{-1}$ of photosynthetically active radiation in incubators at constant $15,20,25,30$, or $35 \mathrm{C}$. In a second study, seeds were germinated in dark incubators with $12 / 12$-h cycles at $10 / 20 \mathrm{C}, 15 / 25 \mathrm{C}$, or 20/30C. The design for both studies was a randomized block with data analyzed separately for each study and combined for both studies by analysis of variance (ANOVA) and the fitting of linear and quadratic regression equations. Pairwise comparisons of mean values were performed using least significant difference (LSD) at $P \leq 0.05$.

Seed moisture content during storage. Seeds were weighed, placed in 9-cm open petri dishes, and dehydrated for $6,12,24,48$, or $72 \mathrm{~h}$ in $40 \mathrm{C}$ forced-draft ovens. Following dehydration, seeds of each replication were reweighed and immediately sealed in screwcapped, 10 -ml, glass vials (100 seeds per vial) and stored at $5 \mathrm{C}$ for 4 weeks. After storage, seeds were reweighed and germinated at a constant 25C. Germination data were analyzed for seed moisture content by ANOVA, fitting linear and quadratic regression equations, and Tukey's HSD procedure. The initial

Table 1. The effect of constant or alternating temperatures on total germination $(\mathrm{G})$ and the number of days to $50 \%$ germination $\left(\mathrm{T}_{50}\right)$ and between $10 \%$ and $90 \%$ germination $\left(\mathrm{T}_{90}-\mathrm{T}_{10}\right)$ of 'Painted Center Dark Eye' gerbera seeds in darkness. Data are the means of four 100-seed replications during 21 days of germination.

\begin{tabular}{|c|c|c|c|c|}
\hline \multicolumn{2}{|c|}{ Temp } & \multicolumn{3}{|c|}{$\begin{array}{c}\text { Germination } \\
\text { responses }\end{array}$} \\
\hline Regime & ${ }^{\circ} \mathrm{C}$ & $\mathrm{G}$ & $\mathrm{T}_{50}$ & $\mathrm{~T}_{90}-\mathrm{T}_{10}$ \\
\hline \multirow[t]{5}{*}{ Constant } & 15 & 86 & 4.8 & 3.1 \\
\hline & 20 & 86 & 4.6 & 3.0 \\
\hline & 25 & 84 & 3.1 & 2.4 \\
\hline & 30 & 76 & 3.5 & 2.6 \\
\hline & 35 & 11 & 4.7 & 4.4 \\
\hline \multirow[t]{3}{*}{ Alternating } & $10 / 20(15)^{\mathrm{z}}$ & 60 & 9.6 & 9.1 \\
\hline & $15 / 25(20)^{\mathrm{z}}$ & 68 & 5.8 & 5.0 \\
\hline & $20 / 30(25)^{\mathrm{z}}$ & 79 & 4.6 & 2.4 \\
\hline $\mathrm{LSD}_{005}$ & & 4.7 & 0.4 & 0.5 \\
\hline
\end{tabular}

${ }^{\mathrm{z}}$ Mean alternating temperature.

Table 2. Coefficient estimates and coefficient of determination value $\left(R^{2}\right)$ for the fitted regression equations relating total germination percentages $(\mathrm{G})$, the number of days to $50 \%$ germination $\left(\mathrm{T}_{50}\right)$ and between $10 \%$ and $90 \%$ germination $\left(\mathrm{T}_{90}-\mathrm{T}_{10}\right)$ to levels of constant and mean alternating temperature. Estimated response $=b_{0}+b_{1}$ temperature $+b_{2}$ temperature ${ }^{2}$, where $b_{0}$ is a constant and $b_{1}$ and $b_{2}$ are the linear effects.

\begin{tabular}{|c|c|c|c|c|c|c|}
\hline \multirow{2}{*}{$\begin{array}{l}\text { Germination } \\
\text { response }\end{array}$} & \multicolumn{2}{|c|}{ Temp } & \multicolumn{4}{|c|}{ Coefficient estimates } \\
\hline & Regime & Range $\left({ }^{\circ} \mathrm{C}\right)$ & $\mathrm{b}_{0}$ & $\mathrm{~b}_{1}$ & $\mathrm{~b}_{2}$ & $R^{2}$ \\
\hline \multirow[t]{2}{*}{$\overline{\mathrm{G}}$} & Constant & $15-30$ & 96.4 & -0.6 & & 0.73 \\
\hline & Constant & $15-35$ & -77.5 & 16.5 & -0.4 & 0.95 \\
\hline \multirow[t]{2}{*}{$\mathrm{T}_{50}$} & Constant & $15-30$ & 6.4 & -0.1 & & 0.66 \\
\hline & Constant & $15-35$ & 12.7 & -0.7 & 0.01 & 0.70 \\
\hline \multirow[t]{2}{*}{$\mathrm{T}_{90}-\mathrm{T}_{10}$} & Constant & $15-30$ & 6.6 & -0.3 & 0.01 & 0.58 \\
\hline & Constant & $15-35$ & 8.7 & -0.5 & 0.01 & 0.81 \\
\hline $\mathrm{G}$ & Alternating & $(15)-(25)$ & 29.8 & 2.0 & & 0.90 \\
\hline & Alternating & $(15)-(25)$ & 35.7 & -2.5 & 0.05 & 0.98 \\
\hline $\mathrm{T}_{90}-\mathrm{T}_{10}$ & Alternating & $(15)-(25)$ & 30.4 & -1.9 & 0.03 & 0.99 \\
\hline
\end{tabular}


seed moisture content was determined by weighing four 100 -seed lots, which were dehydrated at $50 \mathrm{C}$ for $48 \mathrm{~h}$, and reweighing the seed after it cooled to room temperature.

Cold tolerance of seed. Seeds were placed in $15 \times 2.5-\mathrm{cm}$ petri dishes on wire screens supported by segments of tubing $1 \mathrm{~cm}$ above a chemical desiccant. Constant $22 \%$ RH was maintained in the sealed petri dishes by adding $50 \mathrm{ml}$ of saturated potassium acetate to the bottom of each dish (Copeland, 1976). Seeds were placed in a refrigerated incubator at $20 \mathrm{C}$ during the week of dehydration. Following dehydration, seeds were placed immediately in $10-\mathrm{ml}$, sealed, glass vials (100 seeds per vial) and immersed in polyethylene glycolwater $(\mathrm{v} / \mathrm{v})$ in controlled-temperature baths (Guy and Carter, 1984) for 7 days at 5, 0, -5, $-10,-15$, or $-20 \mathrm{C}$. Bath temperatures were lowered $3 \mathrm{C}$ per hour to final temperatures, and that temperature was maintained for 7 days. Then the temperature was increased $4 \mathrm{C}$ per hour to 10C. Following low- or subzero-temperature treatment, seeds were germinated at a constant $25 \mathrm{C}$ as previously described. $\mathrm{G}, \mathrm{T}_{50}$, and $\mathrm{T}_{90}-\mathrm{T}_{10}$ data were analyzed using ANOVA and the fitting of simple regression equations and compared by the LSD procedure.

Seed water content and germination. Seeds were germinated at $25 \mathrm{C}$ on blotter paper moistened with $2.5,5.0,7.5$, or $10 \mathrm{ml} \mathrm{DW}$. The design was a randomized complete block with data analyzed by ANOVA and the fitting of linear and quadratic regression equations. The study was repeated to determine the moisture content after seeds were imbibed with water for $24 \mathrm{~h}$ at each treatment. Seed replications were weighed, imbibed for $24 \mathrm{~h}$, blotted dry, vacuum-aspirated for $15 \mathrm{~min}$ to remove remaining surface moisture, and reweighed. Next, seeds of each replication were placed in open petri dishes, dehydrated in forced-draft ovens at $50 \mathrm{C}$ for $48 \mathrm{~h}$, and reweighed after the seed cooled.

Temperature and relative humidity interactions during seed storage. Immediately af ter harvest, seeds were dusted with captan and stored at $11 \%, 32 \%, 52 \%$, or $75 \% \mathrm{RH}$ and 5 , 15 , or $25 \mathrm{C}$ for $3,6,9$, or 12 months. Humidity treatments were achieved as previously described, except saturated lithium chloride, magnesium chloride, magnesium nitrate, and sodium chloride solutions were used to achieve the desired RH levels. Incubators with refrigeration and heating capacities maintained constant 5,15 , or $25 \mathrm{C}$ during seed storage. After storage, seeds were germinated in petri dishes at constant $25 \mathrm{C}$ in darkness. ANOVA and response surface model fitting techniques using the SAS (1985) general linear model were used to analyze the data for $\mathrm{G}, \mathrm{T}_{50}$, and $\mathrm{T}_{90}$ $\mathrm{T}_{10}$. Within each storage temperature, a randomized complete-block design was used with a factorial treatment structure (four $\times$ four) between RH and storage period. Contour plots of the estimated germination surfaces were generated from the fitted regression models to graphically show the relationship between each of the germination responses and of storage period and $\mathrm{RH}$ at each of the three storage temperatures.

\section{Results}

Germination temperature. Over the range of 15 to $30 \mathrm{C}$ constant temperatures, $\mathrm{G}$ decreased linearly with increasing temperature; however, over the range of 15 to $35 \mathrm{C}$ constant temperatures, $\mathrm{G}$ behaved curvilinearly with increasing temperature (Tables 1 and 2). G increased linearly as the mean alternating temperature increased (Tables 1 and 2). G was higher $(P<0.05)$ at a constant 15,20 , or $25 \mathrm{C}$ than at the corresponding mean alternating cycles of $10 / 20 \mathrm{C}, 15 / 25 \mathrm{C}$, or $20 / 30 \mathrm{C}$, as determined by LSD. The $\mathrm{T}_{50}$ values were lower at 25 and $30 \mathrm{C}$ than at the other constant temperatures, and constant 15,20 , or $25 \mathrm{C}$ had lower $(P$ $<0.05) \mathrm{T}_{50}$ than the corresponding alternating temperatures (Table 1). The $\mathrm{T}_{50}$ values decreased with increasing constant temperature over the 15 to $30 \mathrm{C}$ range but behaved quadratically over the 15 to $35 \mathrm{C}$ range (Tables 1 and 2 ). Over the mean alternating temperatures, the $\mathrm{T}_{50}$ values behaved quadratically. The $\mathrm{T}_{90}-\mathrm{T}_{10}$ span was shortest (2.4 days) at $25 \mathrm{C}$ when constant or when it was the mean of alternating temperatures (Table 1). Over the constant and alternating temperature ranges, the $T_{90}-T_{10}$ values behaved quadratically (Table 2 ). At 15 and $20 \mathrm{C}$, the $\mathrm{T}_{90}-\mathrm{T}_{10}$ spans were shorter $(P \leq$ 0.05 ) at constant temperatures than at the corresponding mean alternating temperatures (Table 1).

Seed moisture tolerance. A quadratic decline in $\mathrm{G}$ occurred during storage as seed moisture content was reduced from $7.1 \%$ to $2.2 \%$ (Table 3). Pairwise comparisons among $\mathrm{G}$ showed no differences between $3.5 \%$ to $7.1 \%$ moisture levels, but $\mathrm{G}$ was lower at $3.0 \%$ and $2.2 \%$ levels than at $7.1 \%$ as determined by Tukey's HSD. The $\mathrm{T}_{50}$ declined quadratically as seed moisture levels were reduced. No differences were found when comparisons were made among $\mathrm{T}_{50}$ values at seed moisture levels from $7.1 \%$ to $3.5 \%$, but $\mathrm{T}_{50}$ increased $(P \leq$ 0.05 ) at $3.0 \%$ and $2.2 \%$ relative to $7.1 \%$ (Table 3). The $T_{90}-T_{10}$ spans increased quadratically as seed moisture levels declined. No differences were found among $T_{90}-T_{10}$ span from $7.1 \%$ to $3.5 \%$ seed moisture levels, but values increased as moisture levels decreased to $<3.5 \%$.

Seed cold tolerance. The $7.1 \%$ moisture content of recently harvested seeds was reduced to $5.1 \%$ during 7 days of storage at $11 \%$ $\mathrm{RH}$ and 20C before low-temperature treatment. Similar G occurred for this seed when stored at 5 to $-5 \mathrm{C}$, but $\mathrm{G}$ decreased slightly at lower storage temperatures (Table 4). No trends in $\mathrm{T}_{50}$ or $\mathrm{T}_{90}-\mathrm{T}_{10}$ values occurred from lowering the storage temperature from 5 to $-20 \mathrm{C}$ (Table 4).

Water content during germination. $\mathrm{G}, \mathrm{T}_{50}$, and $\mathrm{T}_{90}-\mathrm{T}_{10}$ values increased quadratically during germination when the seed moisture content increased from $43.7 \%$ to $55.4 \%$ (Table 5). $\mathrm{G}$ increased from $18 \%$ to $82 \%$ as seed moisture increased from $43.7 \%$ to $51.7 \%$, and $\mathrm{G}$ declined to $70 \%$ at $55.4 \%$ seed moisture content. Both $\mathrm{T}_{50}$ and $\mathrm{T}_{90}-\mathrm{T}_{10}$ values declined as seed moisture contents increased from $43.7 \%$ to $51.7 \%$, indicating more rapid and uniform
Table 3. Effect of reduced seed moisture content during 28 days of storage at $5 \mathrm{C}$ on total germination percentages $(\mathrm{G})$ and the number of days to $50 \%$ germination $\left(\mathrm{T}_{50}\right)$ and between $10 \%$ and $90 \%$ germination $\left(\mathrm{T}_{90}-\mathrm{T}_{10}\right)$ of recently harvested gerbera seeds. Treatments contained four 100 -seed replications germinated in darkness at $25 \mathrm{C}$ during 14 days. Results of tests for trends across moisture levels are indicated.

\begin{tabular}{|c|c|c|c|c|}
\hline Seed & & & & \\
\hline $\begin{array}{l}\text { Desiccation } \\
\text { duration }\end{array}$ & Moisture & Gern & nation & esponses \\
\hline (h) & $(\%)$ & $\mathrm{G}$ & $\mathrm{T}_{50}$ & $\mathrm{~T}_{90}-\mathrm{T}_{10}$ \\
\hline 0 & 7.1 & 83 & 3.1 & 2.4 \\
\hline 6 & 5.7 & 81 & 3.0 & 2.4 \\
\hline 12 & 4.2 & 81 & 3.0 & 2.4 \\
\hline 24 & 3.5 & 80 & 3.0 & 2.8 \\
\hline 48 & 3.0 & 70 & 3.5 & 3.8 \\
\hline 72 & 2.2 & 63 & 4.7 & 5.0 \\
\hline Significance & & & & \\
\hline Linear & & $* * *$ & $* * *$ & $* * *$ \\
\hline Quadratic & & $* * * \mathrm{z}$ & $* * * y$ & $* * * \mathrm{x}$ \\
\hline $\mathrm{HSD}_{0.05}$ & & 5.0 & 0.4 & 0.6 \\
\hline
\end{tabular}

${ }^{\mathrm{z}} \mathrm{G}=30.5+18.6 \mathrm{~m}-1.6 \mathrm{~m}^{2} ; R^{2}=0.85$.

${ }^{\mathrm{y}} \mathrm{T}_{50}=7.8-1.9 \mathrm{~m}+0.2 \mathrm{~m}^{2} ; R^{2}=0.82$.

${ }^{x} \mathrm{~T}_{90}-\mathrm{T}_{10}=9.5-2.6 \mathrm{~m}+0.2 \mathrm{~m}^{2} ; R^{2}=0.91$.

**** Significant at $P \leq 0.001$.

Table 4. Effect of temperature on total germination percentages $(\mathrm{G})$, and the number of days to $50 \%$ germination $\left(\mathrm{T}_{50}\right)$ and between $10 \%$ and $90 \%$ germination $\left(\mathrm{T}_{90}-\mathrm{T}_{10}\right)$ of gerbera seed after lowtemperature storage for 7 days at $5.1 \%$ moisture content. Data are the means of 400 seeds germinated in darkness at $25 \mathrm{C}$ during 14 days. Results of tests for trends across temperature levels are indicated.

\begin{tabular}{|c|c|c|c|}
\hline \multirow{2}{*}{$\begin{array}{l}\text { Temp } \\
\left({ }^{\circ} \mathrm{C}\right)\end{array}$} & \multicolumn{3}{|c|}{ Germination responses } \\
\hline & $\mathrm{G}$ & $\mathrm{T}_{50}$ & $\mathrm{~T}_{90}-\mathrm{T}_{10}$ \\
\hline 5 & 89 & 3.1 & 2.2 \\
\hline 0 & 88 & 3.0 & 2.2 \\
\hline-5 & 87 & 3.2 & 2.2 \\
\hline-10 & 83 & 2.9 & 2.3 \\
\hline-15 & 83 & 2.9 & 2.0 \\
\hline-20 & 82 & 2.9 & 2.0 \\
\hline \multicolumn{4}{|c|}{ Significance } \\
\hline Linear & $*$ & NS & NS \\
\hline $\mathrm{LSD}_{0.05}$ & 4.2 & 0.2 & 0.3 \\
\hline
\end{tabular}

ss, * Nonsignificant or significant at $P \leq 0.05$.

Table 5. Effect of moisture content on total germination percentages $(\mathrm{G})$ and the number of days to $50 \%$ germination $\left(\mathrm{T}_{50}\right)$ and between $10 \%$ and $90 \%$ germination $\left(\mathrm{T}_{90}-\mathrm{T}_{10}\right)$ of gerbera seed. Data are the means of 400 seeds germinated at $25 \mathrm{C}$ during 14 days. Results of test for trends across moisture levels are indicated.

\begin{tabular}{|c|c|c|c|c|}
\hline \multirow{2}{*}{$\begin{array}{l}\text { Substrate } \\
\text { water } \\
(\mathrm{ml})\end{array}$} & \multirow{2}{*}{$\begin{array}{c}\text { Seed } \\
\text { moisture } \\
(\%)\end{array}$} & \multicolumn{3}{|c|}{ Germination responses } \\
\hline & & $G$ & $\mathrm{~T}_{50}$ & $\overline{T_{90}-T_{10}}$ \\
\hline 2.5 & 43.7 & 18 & 5.1 & 4.2 \\
\hline 5.0 & 47.1 & 47 & 3.4 & 2.5 \\
\hline 7.5 & 51.7 & 82 & 3.0 & 2.1 \\
\hline 10.0 & 55.4 & 70 & 3.2 & 2.8 \\
\hline \multicolumn{5}{|l|}{ Significance } \\
\hline Linear & & $* * *$ & $* * *$ & $* * *$ \\
\hline Quadratic & & $* * \mathrm{z}$ & $* * y$ & $* * \mathrm{x}$ \\
\hline
\end{tabular}


germination. The estimated minimum $\mathrm{T}_{50}$ value was 2.8 days at $51.8 \%$ seed moisture content, and the estimated minimum $\mathrm{T}_{90}-\mathrm{T}_{10}$ was 2.0 days at $49.1 \%$. These estimated minimums were calculated from the quadratic equations footnoted in Table 5.

Storage temperature and $R H$. Drawing on inferences from the fitted regression equations (Table 6) and surface contour plots (Fig. 1) generated from the fitted models, total $\mathrm{G}$ decreased at all temperatures as RH levels increased $>32 \%$ and storage periods lengthened from 6 to 12 months (Fig. $1 \mathrm{~A}-\mathrm{C}$ ). No seeds germinated after 3 to 12 months storage at 15 or $25 \mathrm{C}$ and $75 \% \mathrm{RH}$ (hence the shaded regions in Fig. $1 \mathrm{~B}, \mathrm{C}, \mathrm{E}, \mathrm{F}, \mathrm{H}$, and I). At $15 \mathrm{C}, \mathrm{G}$ declined from $75 \%$ to $60 \%$ as storage increased from 3 to 12 months and RH increased from $32 \%$ to $52 \%$ and from $70 \%$ to $30 \%$ at $25 \mathrm{C}$ (Fig. 1 B and C). Similar G occurred after seed storage at $11 \%$ and $32 \% \mathrm{RH}$, with both having $>80 \% \mathrm{G}$ after 12 months storage at $5 \mathrm{C}$ compared to $75 \%$ and $70 \% \mathrm{G}$ after 12 months storage at 15 and $25 \mathrm{C}$, respectively. Maximum estimated germination was $82.2 \%$ for seeds stored 9 months at $22 \% \mathrm{RH}$ and 5C.

The lowest $\mathrm{T}_{50}$ resulted after 9 months of

Table 6. Coefficient estimates and coefficient of determination $\left(R^{2}\right)$ values for the fitted regression models in Fig. 1. Estimated response $=\mathrm{b}_{0}+\mathrm{b}_{1} \mathrm{SP}+\mathrm{b}_{2} \mathrm{RH}+\mathrm{b}_{3} \mathrm{SP}$ $\times \mathrm{RH}+\mathrm{b}_{4} \mathrm{SP}^{2}+\mathrm{b}_{5} \mathrm{RH}^{2}+\mathrm{b}_{6} \mathrm{SP} \times \mathrm{RH}^{2}\left(\mathrm{SP}=\right.$ storage period; $\mathrm{RH}=$ relative humidity $; \mathrm{b}_{1}$ and $\mathrm{b}_{2}=$ linear effects, $\mathrm{b}_{4}$ and $\mathrm{b}_{5}=$ quadratic effects, and $\mathrm{b}_{3}$ and $\mathrm{b}_{6}=$ interactive effects).

\begin{tabular}{|c|c|c|c|c|c|c|c|c|c|c|}
\hline \multirow[b]{2}{*}{ Response } & \multirow{2}{*}{$\begin{array}{l}\text { Temp } \\
\left({ }^{\circ} \mathrm{C}\right)\end{array}$} & \multicolumn{9}{|c|}{ Coefficient estimates } \\
\hline & & $\mathrm{b}_{0}$ & $b_{1}$ & $b_{2}$ & $b_{3}$ & $\mathrm{~b}_{4}$ & $b_{5}$ & $\mathrm{~b}_{6}$ & $R^{2}$ & Figure \\
\hline \multirow[t]{3}{*}{$\overline{\mathrm{G}}$} & 5 & 76.79 & -0.31 & -0.03 & 0.09 & & $7.2 \times 10^{-4}$ & $-1.9 \times 10^{-3}$ & 0.872 & $1 \mathrm{~A}$ \\
\hline & 15 & 87.55 & -2.02 & -0.76 & 0.17 & & $1.3 \times 10^{-2}$ & $-3.3 \times 10^{-3}$ & 0.659 & $1 \mathrm{~B}$ \\
\hline & 25 & 79.26 & -3.12 & 0.07 & 0.21 & & $2.0 \times 10^{-3}$ & $-5.2 \times 10^{-3}$ & 0.878 & $1 \mathrm{C}$ \\
\hline \multirow[t]{3}{*}{$\mathrm{T}_{50}$} & 5 & 3.44 & -0.12 & -0.02 & $1.1 \times 10^{-3}$ & $4.5 \times 10^{-3}$ & $2.3 \times 10^{-4}$ & & 0.700 & $1 \mathrm{D}$ \\
\hline & 15 & 4.29 & -0.21 & -0.06 & $2.1 \times 10^{-3}$ & $8.6 \times 10^{-3}$ & $8.2 \times 10^{-4}$ & & 0.806 & $1 \mathrm{E}$ \\
\hline & 25 & 3.37 & -0.08 & $-9.9 \times 10^{-3}$ & $-5.3 \times 10^{-3}$ & $8.1 \times 10^{-3}$ & $3.4 \times 10^{-4}$ & $1.1 \times 10^{-4}$ & 0.900 & $1 \mathrm{~F}$ \\
\hline \multirow[t]{3}{*}{$\mathrm{T}_{90}-\mathrm{T}_{10}$} & 5 & 3.54 & -0.20 & -0.06 & $6.1 \times 10^{-3}$ & $2.3 \times 10^{-3}$ & $5.6 \times 10^{-4}$ & $-5.2 \times 10^{-5}$ & 0.458 & $1 \mathrm{G}$ \\
\hline & 15 & 5.61 & -0.63 & -0.18 & $2.8 \times 10^{-2}$ & $2.1 \times 10^{-3}$ & $-1.9 \times 10^{-4}$ & $-1.9 \times 10^{-4}$ & 0.611 & $1 \mathrm{H}$ \\
\hline & 25 & 1.98 & -0.09 & 0.05 & $-9.5 \times 10^{-3}$ & $1.2 \times 10^{-2}$ & $-6.9 \times 10^{-4}$ & $1.9 \times 10^{-4}$ & 0.844 & $1 \mathrm{I}$ \\
\hline
\end{tabular}
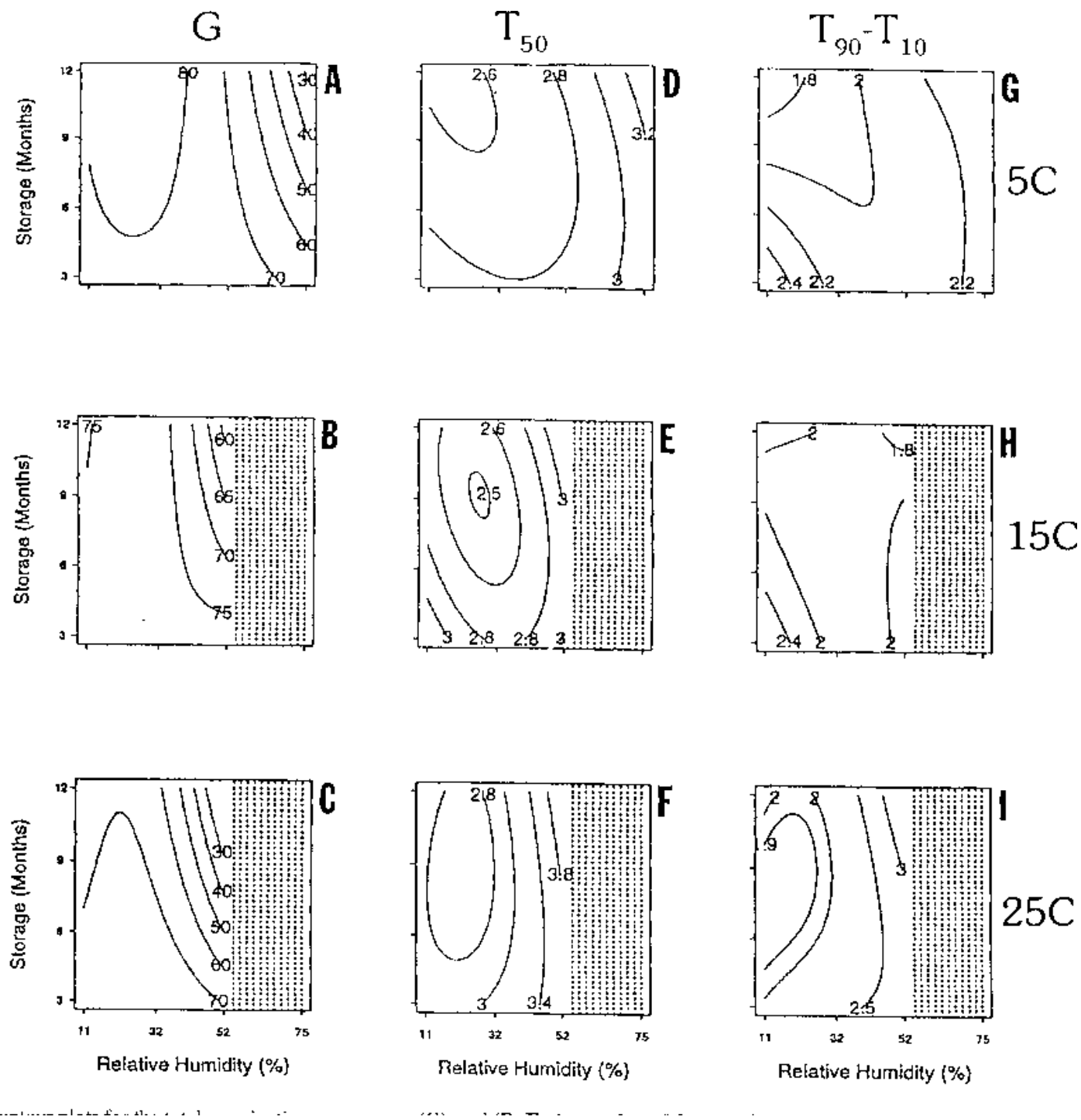

Fig. 1. (A-C) Contour plots for the total germination percentages $(\mathrm{G})$, and (D-F) the number of days to $50 \%$ germination $\left(\mathrm{T}_{50}\right)$ and $(\mathbf{G}-\mathbf{I})$ between $10 \%$ and $90 \%$ germination $\left(\mathrm{T}_{90}-\mathrm{T}_{10}\right)$ for gerbera seeds germinated at $25 \mathrm{C}$ in darkness following storage at $11 \%$ to $75 \%$ relative humidity for 3 to 12 months at (A, D, G) 5, $(\mathbf{B}, \mathbf{E}, \mathbf{H}) 15$, or $(\mathbf{C}, \mathbf{F}, \mathbf{I}) 25 \mathrm{C}$. Regression equations used to generate these plots are listed in Table 6. (B-I) The shaded regions signify that no seeds germinated after storage at $>52 \% \mathrm{RH}$ at 15 or $25 \mathrm{C}$. 
storage at $32 \% \mathrm{RH}$ or $15 \mathrm{C}$ (Fig. 1E). Seeds stored at 5 or $15 \mathrm{C}$ and $11 \%$ to $32 \% \mathrm{RH}$ required 2.6 to 2.8 days for $\mathrm{T}_{50}$, but 2.8 to 3.0 days were required after storage at $25 \mathrm{C}$ (Fig. 1D-F). The longest delay in $\mathrm{T}_{50}$ was after seed storage at $25 \mathrm{C}$ and $52 \% \mathrm{RH}$; seed failed to germinate after storage at $75 \% \mathrm{RH}$ and 15 or 25C. The spans in $\mathrm{T}_{90}-\mathrm{T}_{10}$ were similar $(\leq 2.5$ days) for seeds stored at $11 \%$ and $32 \% \mathrm{RH}$ levels at all temperatures (Fig. 1G-I).

\section{Discussion}

Gerbera seed germination can be optimized by manipulating the environmental conditions during storage. Similar $G, \mathrm{~T}_{50}$, and $\mathrm{T}_{90}-\mathrm{T}_{10}$ were found in darkness or continuous light at $15 \mu \mathrm{mol} \cdot \mathrm{m}^{-2} \cdot \mathrm{s}^{-1}$ at $25 \mathrm{C}$ (data not presented). Uniform $\mathrm{G}$ occurred at constant 15,20 , or $25 \mathrm{C}$, which is a broader optimum temperature range than the ones recommended by Ball (1991) or Cathey (1976). Higher $G$ and shorter $\mathrm{T}_{50}$ or $\mathrm{T}_{90}-\mathrm{T}_{10}$ values resulted at constant 15 , 20 , or $25 \mathrm{C}$ compared to alternating $12 / 12-\mathrm{h}$ cycles of $10 / 20 \mathrm{C}, 15 / 25 \mathrm{C}$, or $20 / 30 \mathrm{C}$ with corresponding means. Bewley and Black (1982) reported that alternating daily temperatures delayed the germination of seed not requiring low temperatures to terminate seed dormancy. Carpenter and Ostmark (1988) and Carpenter et al. (1991) reported that amaryllis (Hippeastrum $\times$ hybridum Hort.) and gladiolus (Gladiolus grandiflorus Andr.), species lacking seed dormancy, had maximum $\mathrm{G}$ at optimum constant temperatures and significantly lower levels at 12-h alternating temperatures.

Improved practices and technology in the seed production industry have promoted the drying of freshly harvested seeds to low moisture levels for storage and shipment in sealed packages. It is important to know if excessive drying causes losses in seed viability or vigor. Our study showed that a significant decline in G occurred when the $7.1 \%$ moisture content of gerbera seeds at harvest was allowed to decline to $<3.5 \%$ during storage, and the $\mathrm{T}_{50}$ and $\mathrm{T}_{90}-\mathrm{T}_{10}$ increased at seed moisture $\leq 3.5 \%$ and $4.2 \%$, respectively. These results indicate the importance of controlling and limiting the moisture loss from the seed. Justice and Bass (1978) reported that delayed and irregular germination are the first indicators of injury from excessively low seed moisture contents during storage.
Bewley and Black (1982) reported that seed at moisture contents $<14 \%$ do not form ice crystals within the cells when stored at $<0 C$. Justice and Bass (1978) found subzero temperatures were best for long-term seed storage; the seed respiration rate is low at $\angle 0 \mathrm{C}$. Delphinium $\times$ cultorum Voss seed had no loss in total germination or vigor after storage for 5 years at $-15 \mathrm{C}$ (Barton, 1932). In our study, gerbera seed with $5.1 \%$ moisture had no loss in $\mathrm{G}$ after storage from -5 to $5 \mathrm{C}$, but $\mathrm{G}$ was lower after storage at $-10 \mathrm{C}$ or lower (Table 3 ). $\mathrm{T}_{50}$ and $\mathrm{T}_{90}-\mathrm{T}_{10}$ were unchanged after seed storage at -20 to $5 \mathrm{C}$ for 7 days, indicating that gerbera seeds are relatively cold tolerant. Carpenter and Boucher (1992) found that reduced $\mathrm{G}$ and delayed and irregular germination of vinca [Catharanthus roseus (L.) G. Don] seed occurred after storage at subzero temperatures.

Seed moisture content during the 12-month storage study had a major effect on germination. The highest $\mathrm{G}$ and lowest $\mathrm{T}_{50}$ and $\mathrm{T}_{90}-\mathrm{T}_{10}$ values occurred after storage at $5 \mathrm{C}$ and $11 \%$ or $32 \% \mathrm{RH}$ for seeds having $4.5 \%$ and $5.8 \%$ moisture content, respectively. Seeds stored at $5 \mathrm{C}$ and $75 \% \mathrm{RH}$ had $7.9 \%$ moisture content, and $\mathrm{G}$ declined from $85 \%$ to $30 \%$ during 12 months of storage. No seeds germinated after 3 months of storage at 15 or $25 \mathrm{C}$ and $75 \% \mathrm{RH}$ when seed moisture was $8.2 \%$ and $8.4 \%$, respectively. Gerbera seed tolerated low moisture contents during storage but not levels higher than at seed harvest. Bewley and Black (1982) reported that seed deterioration rate during storage depends on the seed water content and temperature and is associated with the rate of food metabolism and respiratory activity. Species having nondormant seeds when shed from the mother plant and that can germinate over a wide temperature range have the most rapid deterioration when stored at high moisture levels (Justice and Bass, 1978).

Seeds of most species have the highest $\mathrm{G}$ between $35 \%$ and $60 \%$ moisture content. Copeland (1976) reported that the optimum seed moisture percentages for germinating corn (Zea mays L.), pea (Pisum sativum L.), soybean [Glycine max (L.) Merrill], and wheat (Triticum aestivum L.) were 32\%, 60\%, 51\%, and $41 \%$, respectively. Carpenter and Maekawa (1991) found 60\% moisture content was optimum for 'Romance Scarlet' verbena (Verbena $\times$ hybrida Voss) seed germination, with rapidly declining $\mathrm{G}$ at $<56 \%$ and $>63 \%$ moisture.
Gerbera seed moisture during germination governed the $\mathrm{G}, \mathrm{T}_{50}$, and $\mathrm{T}_{90}-\mathrm{T}_{10}$ values. Maximum G $(82 \%)$ was at $52 \%$ seed moisture, with $47 \% \mathrm{G}$ at $47 \%$ moisture (Table 4 ). These results indicate that gerbera seeds have a narrow moisture tolerance range for best germination. The seeds required free water in the germination substrate to achieve $52 \%$ moisture content, but higher levels reduced G. Differences in seed moisture content during germination could contribute to variability in $\mathrm{G}$ and the irregular rates of germination reported by commercial producers.

\section{Literature Cited}

Ball, V. 1991. Ball red book: Greenhouse growing. 15th ed. Geo. J. Ball Publishing, West Chicago, Ill.

Barton, L.V. 1932. Effect of storage on the viability of delphinimum seeds. Boyce Thompson Inst. Contrib. 4:141-153.

Bewley, J.D. and M. Black. 1982. Physiology and biochemistry of seeds. vol. 2. Viability, dormancy, and environmental control. SpringerVerlag, New York.

Carpenter, W.J. and J.F. Boucher. 1992. Germination and storage of vinca seed is influenced by light, temperature, and relative humidity. HortScience 27:993-996.

Carpenter, W.J. and S. Maekawa. 1991. Substrate moisture level governs the germination of verbena seeds. HortScience 26:1469-1472.

Carpenter, W.J. and E.R. Ostmark. 1988. Sensitivity of seed germination of amaryllis to light and temperature. HortScience 23:1002-1004.

Carpenter, W.J., G.J. Wilfret, and J.A. Cornell 1991. Temperature and relatively humidity govern germination and storage of gladiolus seed. Hort. Sci. 26:1054-1057.

Cathey, H.M. 1976. Seed germination, p. 47-54. In: J.W. Mastalerz (ed.). Bedding plants, 2nd ed. Pennsylvania Flower Grower, University Park.

Copeland, L.O. 1976. Principles of seed science and technology. Burgess, Minneapolis.

Furutani, S.C., B.H. Zandstra, and H.C. Price. 1985 Low temperature germination of celery seeds for fluid drilling. J. Amer. Soc. Hort. Sci. 110:153-156.

Guy, C.L. and J.V.Carter. 1984. Characterization of partially purified glutathione reductase from cold hardened and nonhardened spinach leaf tissue. Cryobiology 21:454-464.

Justice, O.L. and L.N. Bass. 1978. Principles and practices of seed storage. U.S. Dept. Agr. Hdbk. 506.

Post, K. 1949. Florist crop production and marketing. Orange-Judd, New York.

SAS Institute. 1985. SAS user's guide: Statistics version. 5th ed. SAS Institute, Cary, N.C. 